\title{
Overexpression of rice jacalin-related mannose-binding lectin (OsJAC1) enhances resistance to ionizing radiation in Arabidopsis
}

In Jung Jung ${ }^{1 \dagger}$, Joon-Woo Ahn ${ }^{1 \dagger}$, Sera Jung ${ }^{1}$, Jung Eun Hwang ${ }^{2}$, Min Jeong Hong ${ }^{1}$, Hong-ll Choi ${ }^{1}$ and Jin-Baek Kim ${ }^{1 *}$

\begin{abstract}
Background: Jacalin-related lectins in plants are important in defense signaling and regulate growth, development, and response to abiotic stress. We characterized the function of a rice mannose-binding jacalin-related lectin (OsJAC1) in the response to DNA damage from gamma radiation.

Results: Time- and dose-dependent changes of OsJAC1 expression in rice were detected in response to gamma radiation. To identify OsJAC1 function, OsJAC1-overexpressing transgenic Arabidopsis plants were generated. Interestingly, OsJAC1 overexpression conferred hyper-resistance to gamma radiation in these plants. Using comparative transcriptome analysis, genes related to pathogen defense were identified among 22 differentially expressed genes in OsJAC1-overexpressing Arabidopsis lines following gamma irradiation. Furthermore, expression profiles of genes associated with the plant response to DNA damage were determined in these transgenic lines, revealing expression changes of important DNA damage checkpoint and perception regulatory components, namely MCMS, RPA, ATM, and MRE11.

Conclusions: OsJAC1 overexpression may confer hyper-resistance to gamma radiation via activation of DNA damage perception and DNA damage checkpoints in Arabidopsis, implicating OsJAC1 as a key player in DNA damage response in plants. This study is the first report of a role for mannose-binding jacalin-related lectin in DNA damage.
\end{abstract}

Keywords: Jacalin-related lectin (JRL), lonizing radiation, Transcriptome analysis, DNA damage response (DDR)

\section{Background}

Lectins are carbohydrate-binding proteins that play diverse roles in both plants and animals [1]. In plants, lectins interact with endogenous carbohydrates and reportedly are involved in signaling pathways [2]. Twelve subfamilies of plant lectins have been identified [3]. One subfamily, the jacalin-related lectins (JRLs), is named for the presence of a jacalin-like domain and comprises 25 identified members [4]. This large subfamily has been further divided into two subgroups, based on the members' carbohydrate-binding properties,

\footnotetext{
* Correspondence: jbkim74@kaeri.re.kr

${ }^{\dagger}$ In Jung Jung and Joon-Woo Ahn contributed equally to this work.

${ }^{1}$ Advanced Radiation Technology Institute, Korea Atomic Energy Research

Institute, 29 Geumgu-gil, Jeongeup-si, Jeollabuk-do 56212, Republic of Korea Full list of author information is available at the end of the article
}

subcellular localization, and molecular structures [5]. For example, mannose-binding JRLs are located in both the nucleus and the cytosol, whereas galactose-binding JRLs are located in vascular compartments [5]. Plant JRLs are important in the response to biotic stresses, such as pathogen and insect attack [6], as well as abiotic stresses, such as salinity stress [7]. Functionally, most JRLs are related to disease resistance and signaling in response to multiples stresses [8]. Particularly, JRLs with dirigent domains have been associated with plant defenses to pathogens. OsJAC1 is a mannose-binding JRL from rice (Oryza sativa). This factor contains a dirigent domain in its $\mathrm{N}$-terminal region as described by Jiang et al. [9]. Overexpression of OsJAC1 suppressed elongation of coleoptiles and internodes, consistent

(C) The Author(s). 2019 Open Access This article is distributed under the terms of the Creative Commons Attribution 4.0 International License (http://creativecommons.org/licenses/by/4.0/), which permits unrestricted use, distribution, and 
with a regulatory function for OsJAC1 in growth and development [10]. Furthermore, Weidenbach et al. [11] concluded that this protein is also involved in plant defense to pathogen attack.

The genomes of all organisms are vulnerable to a variety of detrimental endogenous and exogenous factors, including replication errors, reactive oxygen species (ROS), ionizing radiation, and genotoxic chemicals. Ionizing radiation, which includes gamma radiation, is a carcinogen. Gamma irradiation directly damages a genome by introducing doublestrand breaks (DSBs) in the DNA [12]. Repair of DSBs occurs via two important pathways: non-homologous end joining and homologous recombination [13]. In addition, gamma radiation also indirectly induces DNA damage via the generation of ROS, which introduces different types of DNA lesions [14]. Cellular DNA damage response (DDR) mechanisms, including repair mechanisms, to maintain genomic integrity, are fundamentally conserved across all organisms $[15,16]$. One important regulator of DDR is ataxia telangiectasia mutated (ATM) protein [17], which is a signal transducer that acts in response to DSBs. Ataxia telangiectasia and RAD3-related (ATR) protein is also involved in signaling in response to single-strand breaks and stalled replication forks [18].

DNA replication is important for transmission of genetic information to daughter cells and progeny; therefore, all organisms have mechanisms to protect the fidelity of DNA replication. For example, DNA damage can adversely affect the replication machinery and result in a stalled replication fork. DNA replication is initiated at numerous origins of replication in eukaryotes [19] via a two-step process. The first step is origin licensing, which starts with a pre-replicative complex in late mitosis or the G1 phase of the cell cycle [20]. The pre-replicative complex is composed of cell division 6 (CDC6), the originrecognition complex, the cell division cycle 10-dependent transcript 1 (Cdt1), and mini-chromosome maintenance proteins 2-7 (MCM2-MCM7). The second step, origin firing, begins with activation of the MCM2-7 complex. Component kinases, such as cycle dependent kinase (CDK) and Dbf-dependent kinase (DDK), that are specific to the $S$ phase of the cell cycle are required for this origin firing step [20,21].

In our preliminary microarray studies, differential expression of OSJAC1 was found in response to ionizing radiation (unpublished data). Several studies reported that plant JRLs are involved in responses to abiotic and biotic stress [6-8]; however, no evidence for a role of JRLs in DDR has been published. Therefore, we examined the molecular function of OsJAC1 in DDR. We sought to establish the effect of ionizing radiation and abiotic stresses on the expression of OsJAC1. We also generated transgenic OsJAC1overexpressing Arabidopsis lines that were resistant to gamma irradiation. We probed the molecular mechanism underlying OsJAC1 function on DDR using comparative transcriptome analysis of the OsJAC1-overexpressing lines.

\section{Results}

Expression analysis of OSJAC1 in rice plants in response to ionizing radiation, abiotic stresses, and plant hormones

We measured OsJAC1 expression over time in 2-week-old seedlings after exposure to different dosages of gamma radiation. OsJAC1 expression was greatly reduced in rice seedlings immediately after exposure at all levels of irradiation tested (Fig. 1a). Compared to untreated controls, the numbers of OsJAC1 transcripts were reduced approximately 150and 50-fold in plants exposed to 100 and 300 Gy gamma irradiation, respectively. The transcript levels were slightly increased 6,12 , and $24 \mathrm{~h}$ after irradiation compared to the 0 -h time point (Fig. 1b-d); however, by $48 \mathrm{~h}$ after irradiation, we observed a greater than 2-fold induction of OsJAC1 expression in seedlings compared to levels in a non-irradiated control (Fig. 1e). Furthermore, the numbers of transcripts were increased at all doses of irradiation at $168 \mathrm{~h}$ (corresponding to $7 \mathrm{~d}$ ) compared to the unirradiated control. These increases were approximately 30-, 4-, and 8-fold at 100, 200, and $300 \mathrm{~Gy}$ of gamma irradiation, respectively (Fig. 1f). To confirm this late induction of OsJAC1 transcript expression in response to ionizing radiation, dry rice seeds were irradiated with gamma radiation or an ion beam, subsequently germinated on MS media, and irradiated after 2 weeks. These seedlings exhibited increased OsJAC1 transcripts in response to both types of radiation (Fig. 1g, h).

Additionally, OsJAC1 expression was altered by exposure to other stressors. OsJAC1 expression was also upregulated in response to salinity stress (Fig. 2a). In seedlings treated with $\mathrm{NaCl}$ for $6 \mathrm{~h}$, we observed an approximately 8 -fold increase in the number of OsJAC1 transcripts compared to untreated seedlings. The OsJAC1 transcript expression was also slightly increased after $3 \mathrm{~h}$ of exposure to heat stress, although no significant difference was observed after 6 or $12 \mathrm{~h}$ of exposure (Fig. 2b). Expression levels of OsJAC1 were also upregulated by jasmonic acid (JA) and salicylic acid (SA) treatment (Fig. 2c, d). OsJAC1 expression was approximately 40-fold higher $12 \mathrm{~h}$ after JA treatment, while SA treatment resulted in a 5-fold induction of OsJAC1 expression at this time point compared with levels in the untreated control.

\section{Generation of Arabidopsis OsJAC1-overexpressing lines}

We next sought to probe the molecular function of OsJAC1 by generating OsJAC1-overexpressing Arabidopsis lines. A schematic diagram (Fig. 3a) shows the structure of the OsJAC1-overexpressing construct in which OsJAC1 is regulated by the $35 S$ promoter and terminator. Two transgenic lines, \#16-6 and \#18-2, displayed significant overexpression, approximately 70- and 130-fold, respectively (Fig. 3b). OsJAC1 overexpression was accompanied by higher levels of OsJAC1 protein in both transgenic lines than in a wild-type control (Fig. 3c). Figure 3d displays the morphology of the transgenic lines in the early vegetative growth stage, revealing 
(a)

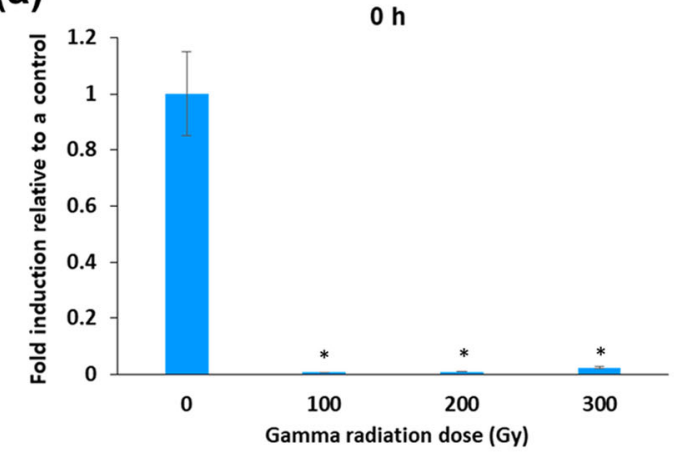

(c)

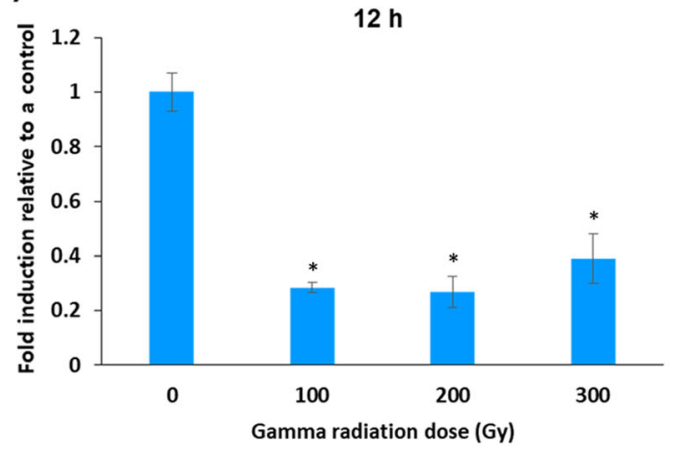

(e)

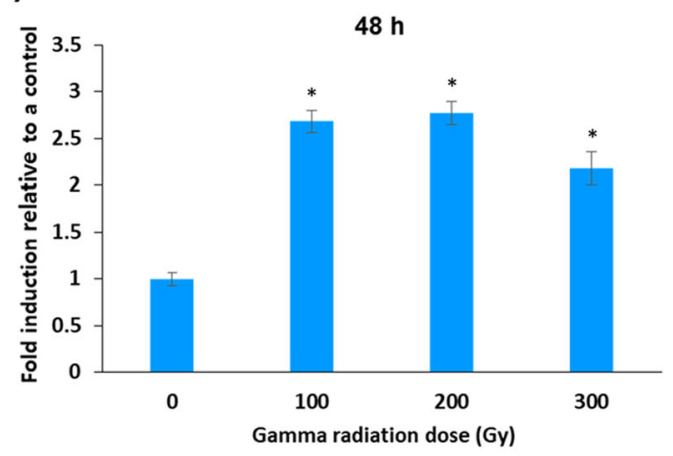

(g)

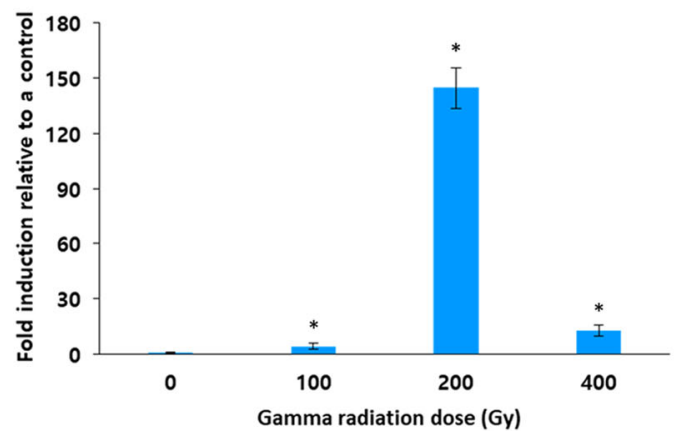

(b)

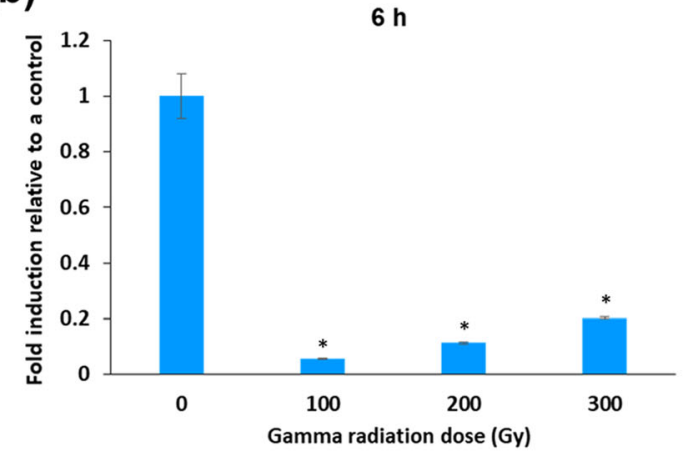

(d)

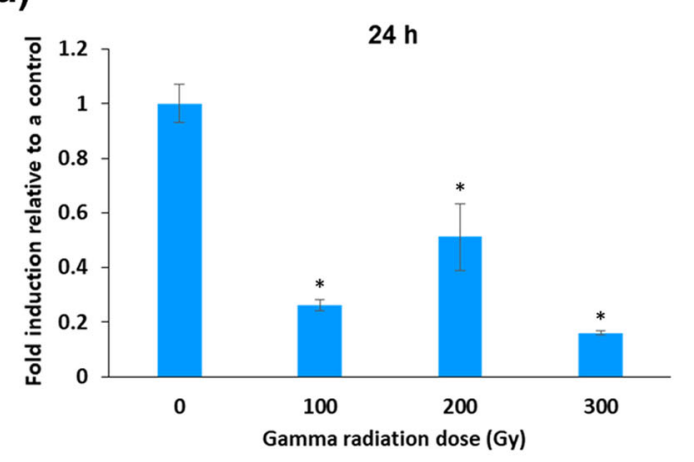

(f)

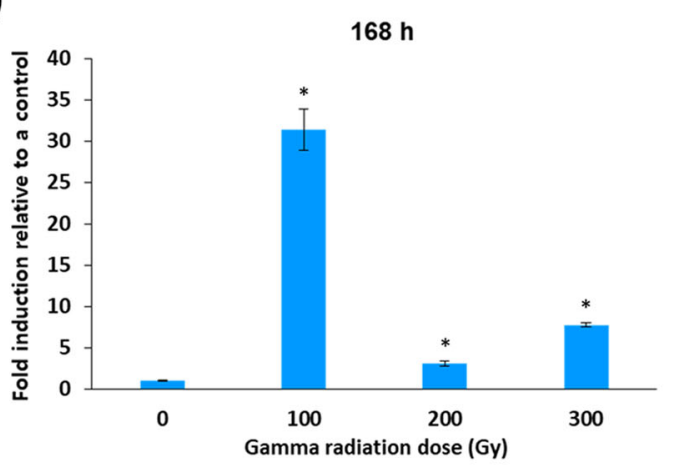

(h)

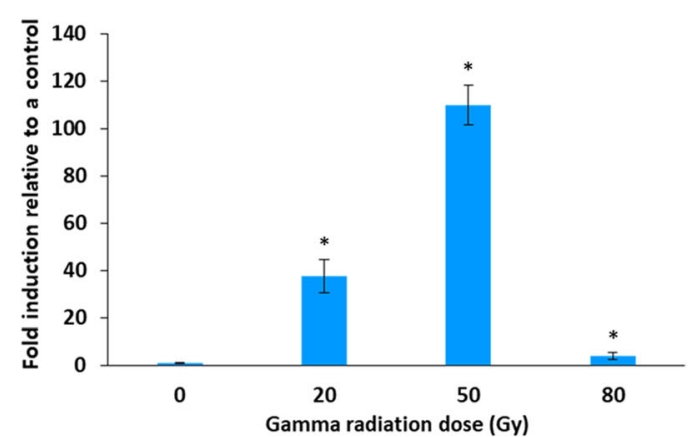

Fig. 1 (See legend on next page.) 
(See figure on previous page.)

Fig. 1 Expression of OSJAC1 in rice seedlings irradiated with ionizing radiation as determined with quantitative RT-PCR. a-f: Time courses of expression of OsJAC1 in 2-week-old rice seedlings after exposure to the indicated levels of gamma radiation. $\mathbf{g}, \mathbf{h}$ : Expression of OsJAC1 in 2week-old seedlings from rice seeds that had been irradiated with gamma radiation ( $\mathbf{g}$ ) or with an ion beam (h) and then germinated on MS media. Values represent means \pm SD $(n=3)$. Statistical analysis was carried out by one-way ANOVA $\left({ }^{*} p<0.01\right)$

no obvious morphological differences in the transgenic lines in comparison to a wild-type control in the absence of exposure to radiation.

\section{OsJAC1 overexpression leads to hyper-resistance to gamma radiation}

We then assessed the effect of OsJAC1 overexpression on growth and development in response to gamma radiation. Transgenic lines and wild-type control plants were irradiated with 200 or $300 \mathrm{~Gy}$ gamma radiation, and growth rates were compared 2 weeks later. There were no morphological differences between the transgenic and control plants in the reproductive stage in the absence of irradiation (Fig. 4a). Following irradiation, the OsJAC1overexpressing lines grew faster than wild-type plants at both doses of irradiation (Fig. 4a). Consequently, the overexpressing lines were taller and accumulated more mass than the irradiated control plants (Fig. 4b, c). Specifically, both OsJAC1-overexpressing lines displayed plant heights and fresh weights that were more than 3-fold higher than those in controls after treatment with $300 \mathrm{~Gy}$ gamma radiation.
We also measured the growth rates of OsJAC1overexpressing lines treated with $\mathrm{NaCl}$ as a means to impose salinity stress. OsJAC1 overexpression enhanced root growth in the stressed plants compared to unstressed plants (Additional file 1: Figure S1). Therefore, we conclude that plants with OsJAC1 overexpression possess resistances to both gamma radiation and salinity stress.

\section{Transcriptomic analysis of the DNA damage response in OsJAC1-overexpressing lines}

Our next step was to probe the molecular function of OsJAC1 in DDR. We performed transcriptome analysis of OsJAC1-overexpressing lines. A total of more than 129 million trimmed reads were generated from a wild-type control and two OsJAC1-overexpressing transgenic lines treated with or without gamma irradiation (Table 1). Trimmed reads were mapped to the reference gene set from the ARAPORT database (https://www.araport.org/). The average mapped rate of six samples was $84 \%$ (Table 1). Figure 5 shows the number of upregulated and downregulated DEGs in both OsJAC1-overexpressing lines compared to the wild-type (a)

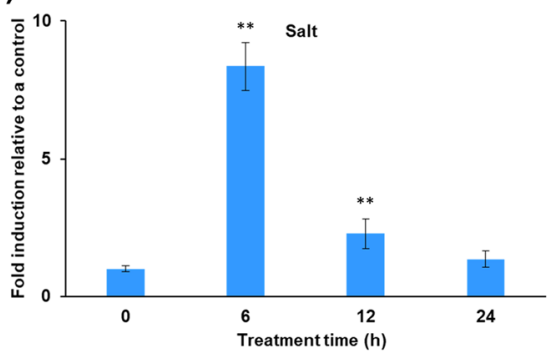

(c)

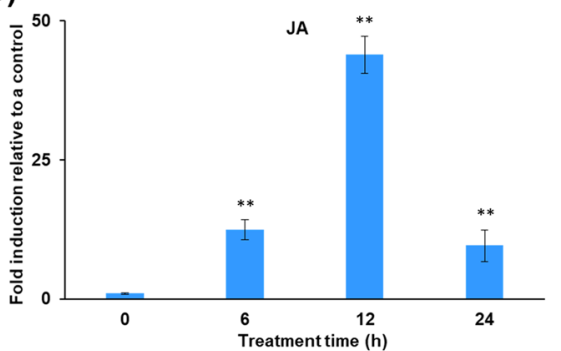

(b)

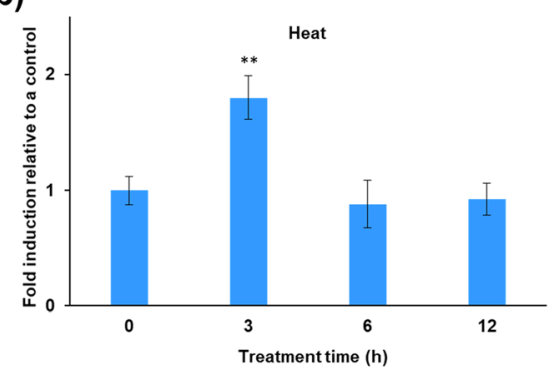

(d)

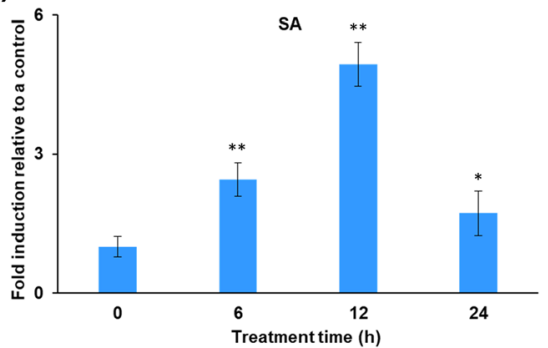

Fig. 2 Time course of expression of OsJAC1 in 2-week-old rice seedlings exposed to abiotic stresses (a) salinity stress or (b) heat stress or to plant hormones (c) SA or (d) JA as determined by quantitative RT-PCR. Data represent means \pm SD $(n=3)$. One-way ANOVA was used for statistical analysis $\left({ }^{* *} p<0.01,0.01<* p<0.05\right)$ 
(a)

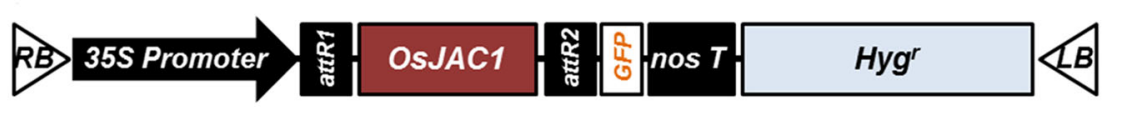

(b)

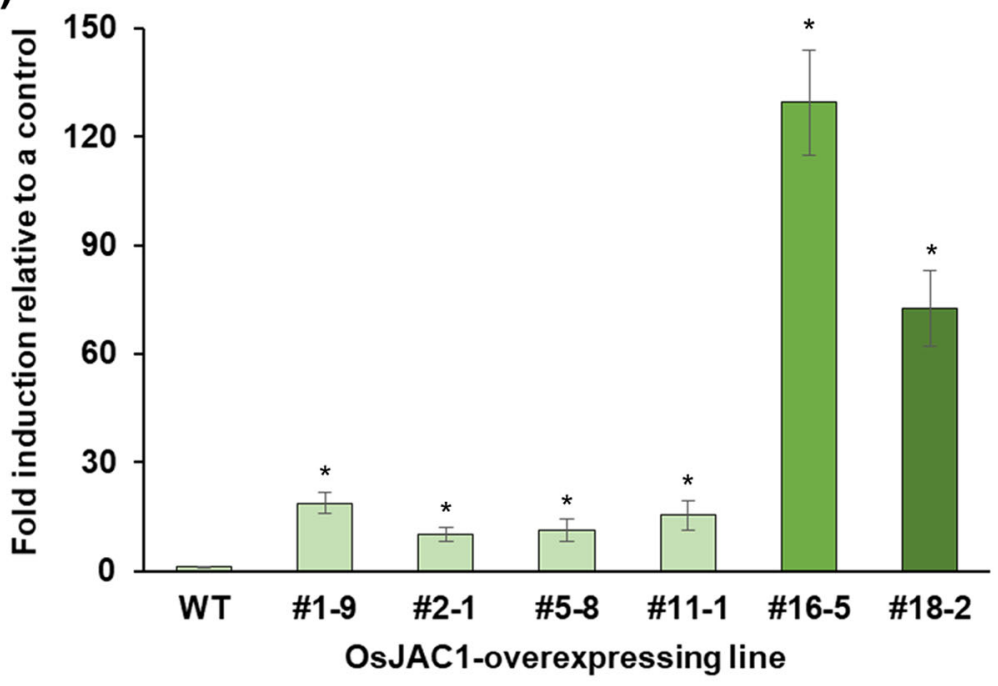

(c)

OsJAC1-overexpressing line

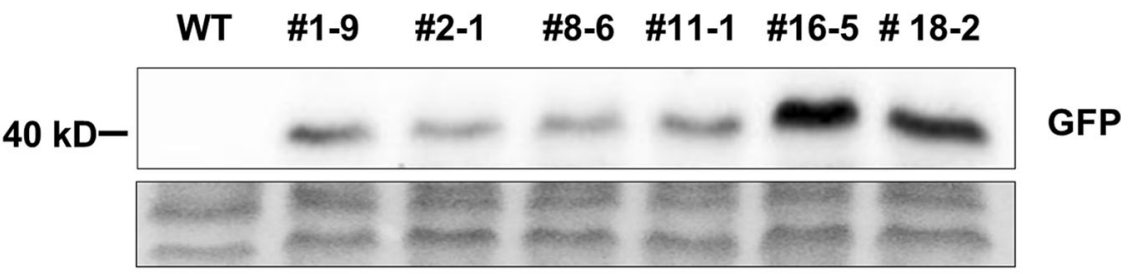

(d)

OsJAc1-

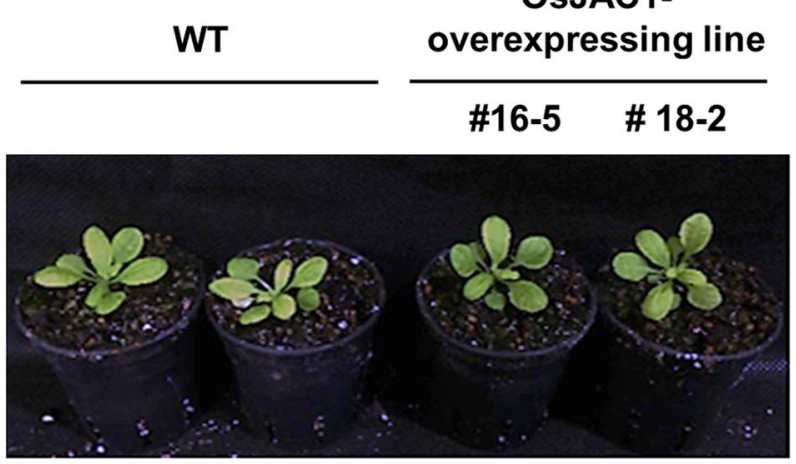

Fig. 3 (See legend on next page.) 
(See figure on previous page.)

Fig. 3 Generation of OsJAC1-overexpressing Arabidopsis lines and confirmation of enhanced expression. a Schematic diagram of vector construct for OsJAC1 overexpression. b OsJAC1 transcripts in OsJAC1-overexpressing lines were detected using quantitative RT-PCR. Data represent means \pm SD $(n=3)$. Statistical analysis was carried out by one-way ANOVA ( $\left.{ }^{*} p<0.01\right)$. c Expression levels of OsJAC1 in OsJAC1-overexpressing lines as determined using western blot. $\mathbf{d}$ Photographs of OsJAC1-overexpressing lines and wild-type plants $30 \mathrm{~d}$ after sowing. Note that morphologies are similar

control after 100 Gy gamma irradiation. The two transgenic lines shared 12 upregulated and 10 downregulated DEGs. In upregulated DEGs, three xyloglucan endotransglucosylase/ hydrolase genes (AT4G14130, AT3G23730, and AT5G65730) were detected (Table 2). Interestingly, pathogen defenserelated genes, such as disease resistance proteins (AT5G41740 and AT5G41750) and NPR1-like protein (AT5G45110), were among the downregulated DEGs of both OsJAC1overexpressing lines. Additional file 2: Table S1 shows expression data for all annotated transcripts in OsJAC1overexpressing lines..

We next assessed the expression profile of genes involved in DNA replication in OsJAC1-overexpressing lines with and without gamma irradiation (Fig. 6). In the absence of irradiation, expression of MCM5, 6, and 7 was greater in OsJAC1-overexpressing lines than in the wild-type control. Following irradiation, the expression of MCM6 and MCM7 was significantly upregulated in OsJAC1-overexpressing lines compared to the irradiated control plant.

Additionally, the transcript level of At1g23750 (replication protein A1) was significantly reduced by OsJAC1 overexpression in the absence of irradiation compared to the wild-type control. There were fewer RPA3A and $R P A 3 B$ transcripts in OsJAC1-overexpressing lines without gamma irradiation compared to the wild-type control, whereas gamma irradiation resulted in transcriptional induction of these two genes (Fig. 6). Both POLGAMMA1 and the At5g67100 (DNA polymerase alpha subunit A) gene were upregulated in the transgenic lines in the absence of irradiation compared to the wild-type plants. Similarly, the expression levels of polymerase epsilon subunits TIL1 and TIL 2 were increased by OsJAC1 overexpression under non-irradiated conditions, whereas slight
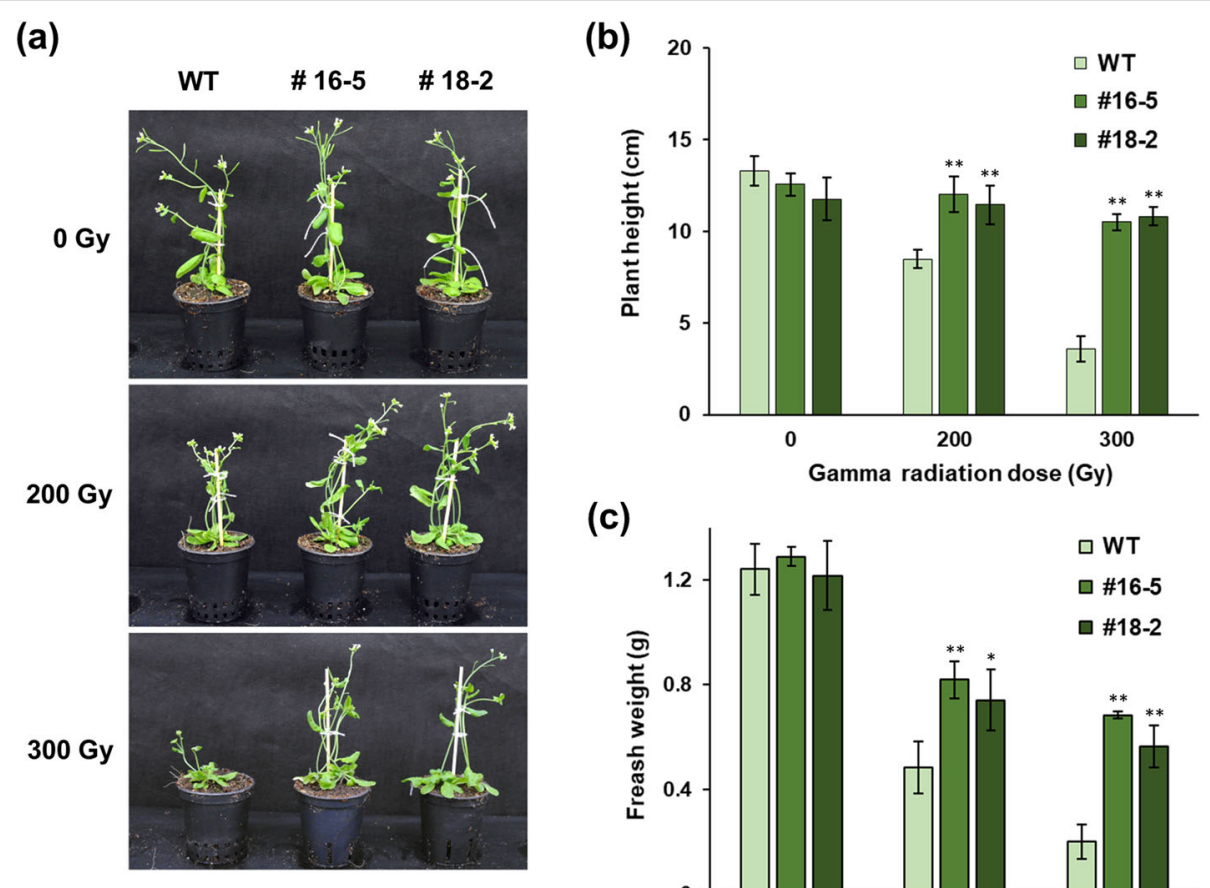

(c)

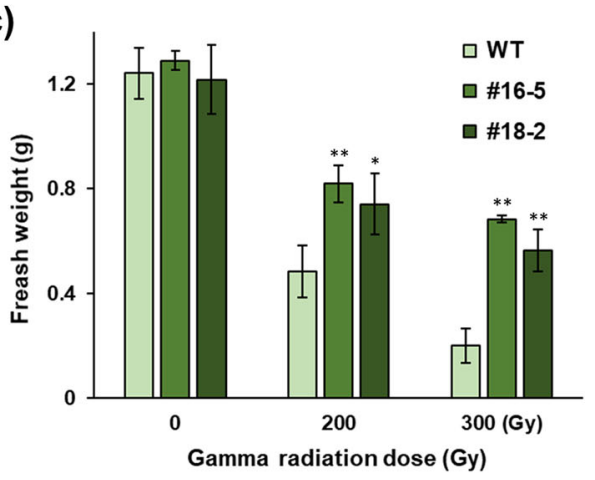

Fig. 4 Morphological features and growth responses of OsJAC1-overexpressing Arabidopsis lines in response to gamma radiation. a Two-week-old seedlings were irradiated using gamma radiation. Photographs of OsJAC1-overexpressing lines and wild-type plants $30 \mathrm{~d}$ after irradiation. b, c Heights and fresh weights of OsJAC1-overexpressing lines and wild-type plants after gamma irradiation. Data represent means $\pm S D(n=3)$. Statistical analysis was carried out by one-way ANOVA $\left({ }^{* *} p<0.01,0.01<{ }^{*} p<0.05\right)$ 
Table 1 Number of trimmed and mapped reads of wild-type and OsJAC1-overexpressing transgenic lines with/without gamma irradiation

\begin{tabular}{llll}
\hline Sample & Total trimmed reads $^{\mathrm{a}}$ & Mapped read & Mapped rate (\%) \\
\hline WT & $23,191,133$ & $19,396,927$ & 83.6 \\
16-5 & $25,199,270$ & $21,188,297$ & 84.0 \\
18-2 & $20,500,887$ & $18,441,540$ & 89.9 \\
WT (100 Gy) & $19,967,350$ & $16,002,371$ & 80.1 \\
16-5 (100 Gy) & $19,971,641$ & $17,370,030$ & 86.9 \\
18-2 (100 Gy) & $21,120,649$ & $16,840,320$ & 79.7 \\
Total & $129,950,930$ & $109,239,485$ & 84.0 \\
\hline
\end{tabular}

${ }^{a}$ All trimmed reads were summed from the two biological replicates of each sample

reductions of these transcripts were observed after gamma irradiation. In addition, gamma irradiation resulted in transcriptional induction of the At1g67320 (DNA primase large subunit) gene in the transgenic lines (Fig. 6).

Figure 7 displays the expression levels of genes involved in homologous recombination repair. OsJAC1 overexpression affected the accumulation of ATM. Expression of this gene was significantly upregulated in non-irradiated OsJAC1-overexpressing lines compared to the wild-type control. Interestingly, we did not detect significant differences in ATR expression between the overexpressing lines and the wild-type control (data not shown). Meiotic recombination 11 (MRE11) and Fanconi anemia group J protein were upregulated by OsJAC1 overexpression in both irradiated and non-irradiated plants (Fig. 7).

Figure 8 shows the expression patterns of genes related to nucleotide excision repair, mismatch repair, and nonhomologous recombination. In nucleotide excision repair, OsJAC1 overexpression enhanced the transcriptional accumulation of $D D B 1 A$ and $D D B 1 B$ (UV-damaged DNA damage-binding proteins) under non-irradiated conditions (Fig. 8a). DNA mismatch repair genes MSH3, MSH6, and
MLH3 were increased in both transgenic lines (Fig. 8b), and gene expression of the non-homologous recombination repair factor At4G57160 (DNA ligase 4) was increased by OsJAC1 overexpression without gamma irradiation (Fig. 8c).

\section{Discussion \\ OsJAC1 is involved in the response to abiotic stress, including gamma irradiation and salinity stress}

JRLs are associated with plant responses to stress, including abiotic stresses and attack by pathogens [8]. The expression of OsJAC1, which encodes a JRL, was upregulated in a time- and dose-dependent manner following exposure to both gamma radiation and an ion beam (Fig. 1). We noted some similarities between these responses and two relevant previous studies. Jin et al. [22], using microarray analysis, observed time- and dosedependent expression of genes associated with signal transduction, transcription, and metabolism in human mesenchymal stem cells exposed to gamma radiation. These genes were either involved in cellular defense, such as apoptosis and responses to stress, or in fundamental cellular processes, such as DNA replication and repair. It has been also been noted that in Chlamydomonas reinhardtii [23], the expression of many DDR genes was altered by gamma irradiation. From the similarities between the response of OsJAC1 and these other genes to radiation, we hypothesized that OsJAC1 may participate in DDR, perhaps in signal transduction involved in these processes.

Given the central role of JRLs in the response of plants to stress, we also examined the response of OsJAC1 expression to salinity stress. Salinity stress, like irradiation, increased OsJAC1 expression in rice (Fig. 2a), and OsJAC1overexpressing lines displayed resistance to salinity stress compared to a wild-type control (Additional file 1: Figure S1). Similar observations were made by Zhang et al. [7], who
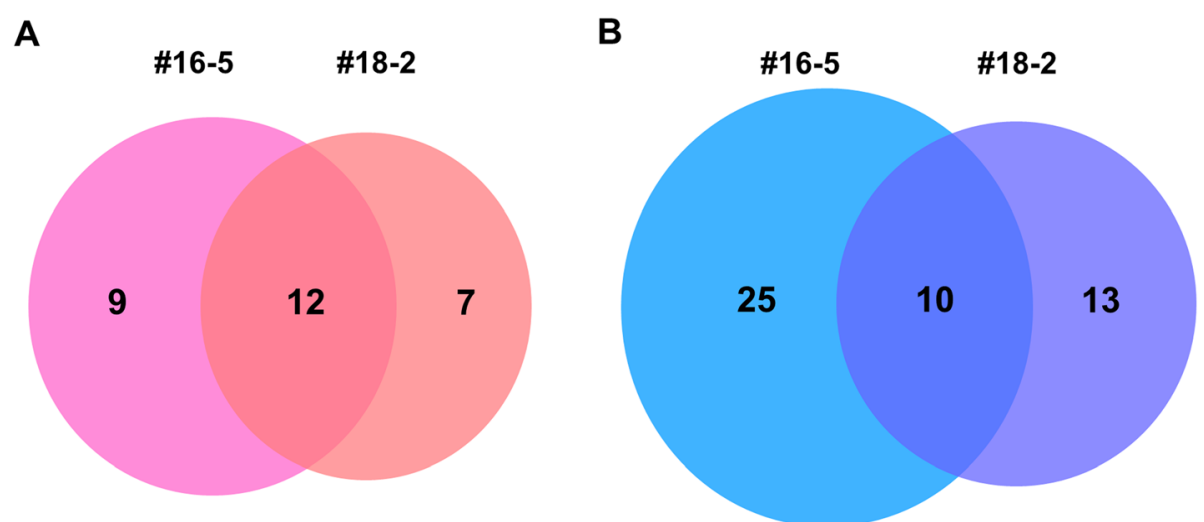

Fig. 5 DEG analysis of OsJAC1-overexpressing Arabidopsis lines compared to a wild-type control after 100 Gy gamma irradiation. Venn diagrams show number of upregulated (a) and downregulated (b) DEGs 
Table 2 Up- and down-regulated DEGs were commonly detected in both OsJAC1-overexpressing lines

\begin{tabular}{|c|c|c|c|c|}
\hline & \multirow[t]{2}{*}{ Locus } & \multicolumn{2}{|c|}{ Fold induction } & \multirow[t]{2}{*}{ Definition } \\
\hline & & $\# 16-5$ & $\# 18-2$ & \\
\hline \multirow[t]{12}{*}{ Up } & AT4G14120 & 2.56 & 2.08 & Unknown \\
\hline & AT4G14130 & 1.75 & 1.89 & Xyloglucan endotransglucosylase/hydrolase 15 \\
\hline & AT3G23730 & 1.57 & 1.54 & Xyloglucan endotransglucosylase/hydrolase 16 \\
\hline & AT2G30600 & 1.28 & 1.51 & BTB/POZ domain-containing protein \\
\hline & AT5G44130 & 1.22 & 1.19 & FASCICLIN-like arabinogalactan protein 13 precursor \\
\hline & AT2G17230 & 1.18 & 1.11 & EXORDIUM like 5 \\
\hline & AT4G25580 & 1.12 & 1.11 & CAP160 protein \\
\hline & AT3G19680 & 1.11 & 1.04 & Protein of unknown function (DUF1005) \\
\hline & AT4G16563 & 1.11 & 1.35 & Eukaryotic aspartyl protease family protein \\
\hline & AT5G46760 & 1.08 & 1.18 & Basic helix-loop-helix (bHLH) DNA-binding family protein \\
\hline & AT5G46750 & 1.05 & 1.01 & ARF-GAP domain 9 \\
\hline & AT5G65730 & 1.01 & 1.01 & Xyloglucan endotransglucosylase/hydrolase 6 \\
\hline \multirow[t]{10}{*}{ Down } & AT5G47910 & -1.83 & -1.47 & Respiratory burst oxidase homologue D \\
\hline & AT5G41750 & -1.76 & -1.70 & Disease resistance protein (TIR-NBS-LRR class) family \\
\hline & AT5G41740 & -1.67 & -1.69 & Disease resistance protein (TIR-NBS-LRR class) family \\
\hline & AT4G34150 & -1.23 & -1.20 & Calcium-dependent lipid-binding (CaLB domain) family protein \\
\hline & AT5G35735 & -1.22 & -1.46 & Auxin-responsive family protein \\
\hline & AT1G61890 & -1.19 & -1.50 & MATE efflux family protein \\
\hline & AT2G38470 & -1.06 & -1.10 & WRKY DNA-binding protein 33 \\
\hline & AT5G45110 & -1.06 & -1.22 & NPR1-like protein 3 \\
\hline & AT4G29780 & -1.05 & -1.93 & Unknown \\
\hline & AT4G33920 & -0.62 & -1.00 & Protein phosphatase $2 \mathrm{C}$ family protein \\
\hline
\end{tabular}

also identified a relationship between lectins and abiotic stresses, including salinity stress, in rice. One effect of salinity stress in plants is the generation of ROS [24], which are also generated by ionizing radiation. ROS damages cellular components, including DNA, in numerous ways $[25,26]$, and these similar responses further strengthen the relationship between OsJAC1 and DDR.

JRLs are regulated by the plant hormones JA and SA, which are related to stress responses and pathogen defense in plants $[11,27,28]$. Thus, we examined the effect of these hormones on expression of OsJAC1. The hormones enhanced transcription of OsJAC1 (Fig. 2c, d). $\mathrm{SA}$ is associated with genotoxic stress that results from exposure to ethyl methanesulphonate and methyl mercuric chloride [29] and may enhance the genotoxic stress-related signaling pathway [30]; however, the role of SA in this signaling remains unclear [31]. These hormones play central roles in the plant defense response to ROS [32, 33], and their signaling pathways were affected in a dose-dependent manner by $\mathrm{H}_{2} \mathrm{O}_{2}$ accumulation in the cat2 Arabidopsis mutant [34, 35]. Similarly, silencing of mannose-binding lectin (CaMLB1) transcript led to a reduction in both disease resistance and ROS accumulation in pepper plants [36]. Furthermore, Weidenbach et al. [11] reported that OsJAC1 mediated the pathogen defense response in rice. Interestingly, however, DEG analysis displayed downregulation of pathogen defenserelated genes in OsJAC1-overexpressing lines (Table 2). These results suggest that OsJAC1 regulates different stresses, such as DNA damage and pathogen attack, via coordination with levels of ROS in plants.

\section{OsJAC1 overaccumulation leads to modulation of DNA replication components}

The relationship between OsJAC1 and abiotic stresses is well documented [7], but the molecular function of this protein has not been established. We first probed the molecular function of OsJAC1 in DDR following exposure of plants to gamma radiation. Arabidopsis lines overexpressing OsJAC1 showed tolerance to gamma radiation (Fig. 4). In addition, DEG analysis revealed that these transgenic lines highlighted differential expression of genes involved in pathogen defense after gamma irradiation (Fig. 5 and Table 2). OsJAC1 functions in pathogen defense have been well characterized previously [11]. Hadwiger et al. [37] also reported that DDR is closely associated with pathogen defense via SA signaling. Thus, differential expression of pathogen-related 


\begin{tabular}{|c|c|c|c|c|c|}
\hline Gene locus & Gene name (definition) & wt vs. \#16-5 & wt vs. \#18-2 & $\begin{array}{l}\text { wt 100Gy vs. } \\
\# 16-5 \text { 100Gy }\end{array}$ & $\begin{array}{l}\text { wt 100Gy vs. } \\
\# 18-2 \text { 100Gy }\end{array}$ \\
\hline AT1G44900 & DNA replication licensing factor (MCM2) & 0.29 & 0.37 & 0.09 & 0.39 \\
\hline AT5G46280 & DNA replication licensing factor $(M C M 3)$ & 0.27 & 0.42 & 0.17 & 0.30 \\
\hline AT2G16440 & DNA replication licensing factor (MCM4) & 0.52 & 0.48 & 0.29 & 0.37 \\
\hline АT2G07690 & DNA replication licensing factor (MCM5) & 0.45 & 0.53 & 0.25 & 0.37 \\
\hline AT5G44635 & DNA replication licensing factor (MCMG) & 0.57 & 0.63 & 0.88 & 0.98 \\
\hline AT4G02060 & DNA replication licensing factor (MCM7) & 0.07 & 0.24 & 0.61 & 0.62 \\
\hline AT1G10590 & Replication factor $\boldsymbol{A} 1$ & -0.38 & -0.13 & 0.52 & 0.23 \\
\hline AT1G23750 & Replication factor $\boldsymbol{A 1}$ & -0.79 & -0.92 & -0.09 & -0.13 \\
\hline AT2G33845 & Replication factor $\boldsymbol{A 1}$ & -0.32 & -0.20 & 0.23 & 0.03 \\
\hline AT4G28440 & Replication factor $\boldsymbol{A} 1$ & -0.45 & -0.32 & 0.34 & -0.21 \\
\hline AT4G19130 & Replication factor $\boldsymbol{A} 1$ & -0.24 & 0.17 & 0.16 & 0.09 \\
\hline AT2G06510 & Replication factor A1 (RPA1A) & 0.22 & 0.14 & -0.09 & 0.10 \\
\hline AT5G08020 & Replication factor A1 (RPA1B) & 0.24 & 0.19 & 0.46 & 0.18 \\
\hline AT5G45400 & Replication factor A1 (RPA70C) & -0.47 & -0.17 & 0.16 & 0.05 \\
\hline AT5G61000 & Replication factor A1 (RPA7OD) & 0.18 & 0.25 & 0.47 & 0.54 \\
\hline AT2G24490 & Replication factor $A 2$ (RPA2A) & 0.00 & 0.02 & 0.07 & -0.09 \\
\hline АT3G02920 & Replication factor A2 (RPA2B) & -0.41 & -0.33 & 0.02 & -0.05 \\
\hline АT3G52630 & Replication factor A3 (RPA3A) & -0.83 & -0.23 & 0.86 & 0.45 \\
\hline AT4G18590 & Replication factor A3 (RPA3B) & -1.00 & -0.59 & 0.63 & 0.27 \\
\hline AT5G22010 & Replication factor C subunit 1 (RFC1) & 0.34 & 0.32 & -0.09 & -0.04 \\
\hline AT1G63160 & Replication factor C subunit 2/4 (RFC2) & 0.09 & 0.07 & 0.49 & 0.54 \\
\hline AT1G77470 & Replication factor C subunit $3 / 5$ (RFC3) & -0.07 & 0.09 & 0.40 & 0.14 \\
\hline AT5G27740 & Replication factor C subunit $3 / 5$ & -0.29 & -0.21 & 0.53 & 0.51 \\
\hline AT1G21690 & Replication factor C subunit $2 / 4$ & -0.40 & -0.10 & 0.25 & 0.06 \\
\hline AT1G07370 & Proliferating cell nuclear antigen (PCNA1) & -0.54 & -0.27 & 0.50 & 0.34 \\
\hline AT2G29570 & Proliferating cell nuclear antigen (PCNA2) & -0.22 & -0.05 & 0.41 & 0.13 \\
\hline AT3G20540 & DNA polymerase / (POLGAMMA1) & 0.81 & 0.60 & -0.02 & 0.17 \\
\hline AT1G50840 & DNA polymerase I (POLGAMMA2) & 0.42 & 0.41 & -0.16 & -0.13 \\
\hline AT5G67100 & DNA polymerase alpha subunit $A$ & 0.77 & 0.72 & 0.07 & 0.24 \\
\hline AT1G67630 & DNA polymerase alpha subunit B (POLAZ) & 0.42 & 0.49 & 0.37 & 0.52 \\
\hline AT5G41880 & DNA primase small subunit (POLA3) & -0.04 & 0.40 & 0.44 & 0.68 \\
\hline AT1G67320 & DNA primase large subunit & -0.14 & 0.02 & 0.87 & 0.73 \\
\hline AT1G08260 & DNA polymerase epsilon subunit 1 (TIL1) & 0.70 & 0.63 & -0.34 & -0.14 \\
\hline AT2G27120 & DNA polymerase epsilon subunit 1 (TIL2) & 1.03 & 1.03 & -0.40 & -0.19 \\
\hline AT5G22110 & DNA polymerase epsilon subunit 2 (DPB2) & -0.35 & -0.19 & 0.11 & 0.39 \\
\hline AT2G27470 & DNA polymerase epsilon subunit 3 (NF-YB11) & -0.35 & -0.16 & 0.44 & 0.24 \\
\hline AT5G63960 & DNA polymerase delta subunit 1 (POLD1) & 0.47 & 0.52 & -0.07 & -0.15 \\
\hline AT2G42120 & DNA polymerase delta subunit 2 (POLD2) & -0.34 & -0.11 & 0.07 & 0.01 \\
\hline AT1G78650 & DNA polymerase delta subunit 3 (POLD3) & -0.11 & -0.32 & 0.35 & 0.33 \\
\hline AT1G09815 & DNA polymerase delta subunit 4 (POLD4) & -0.57 & -0.15 & 0.33 & -0.05 \\
\hline AT1G08840 & DNA replication ATP-dependent helicase (Dna2) & 0.31 & 0.34 & -0.04 & -0.24 \\
\hline AT2G25100 & Ribonuclease $H 2$ subunit $A$ & -0.01 & -0.06 & 0.56 & 0.54 \\
\hline AT4G20325 & Ribonuclease $H 2$ subunit $B$ & -0.72 & -0.37 & -0.23 & -0.11 \\
\hline АT2G39440 & Ribonuclease H2 subunit C & -0.42 & -0.30 & 0.41 & 0.17 \\
\hline AT1G49250 & DNA ligase 1 & -0.43 & -0.11 & -0.37 & -0.14 \\
\hline AT1G08130 & DNA ligase 1 (LIG1) & 0.44 & 0.23 & 0.13 & 0.26 \\
\hline AT3G18580 & Single-strand DNA-binding protein & -0.87 & -0.51 & 0.95 & 0.44 \\
\hline AT5G26680 & Flap endonuclease-1 & 0.04 & 0.25 & 0.13 & -0.04 \\
\hline
\end{tabular}

Fig. 6 Comparative transcriptome expression profiles of genes involved in DNA replication from OsJAC1-overexpressing lines and a wild-type control before and after gamma irradiation 


\begin{tabular}{|c|c|c|c|c|c|}
\hline Gene locus & Gene name (definition) & wt vs. \#16-5 & wt vs. \#18-2 & $\begin{array}{l}\text { wt } 100 \mathrm{~Gy} \text { vs. } \\
\# 16-5 \text { 100Gy }\end{array}$ & $\begin{array}{l}\text { wt 100Gy vs. } \\
\# 18-2 \text { 100Gy }\end{array}$ \\
\hline AT2G32000 & DNA topoisomerase III & 0.23 & 0.07 & 0.03 & 0.09 \\
\hline AT5G63920 & DNA topoisomerase III & 0.30 & 0.30 & 0.16 & -0.06 \\
\hline AT3G32920 & Recombination protein $\operatorname{Rec} A$ & -0.3 & -0.36 & -0.03 & -0.26 \\
\hline AT1G79050 & Recombination protein RecA (RECA1) & 0.08 & 0.18 & 0.07 & -0.14 \\
\hline AT2G19490 & Recombination protein RecA (RECA2) & -0.60 & -0.29 & 0.31 & 0.21 \\
\hline AT2G01440 & ATP-dependent DNA helicase (RecG) & 0.57 & 0.54 & -0.24 & -0.14 \\
\hline AT5G20850 & $D N A$ repair protein (RAD51) & -0.57 & -0.16 & 0.19 & -0.10 \\
\hline AT3G48190 & Ataxia telangiectasia mutated family protein (ATM) & 0.82 & 0.92 & -0.24 & -0.28 \\
\hline AT4G00020 & Breast cancer 2 susceptibility protein (BRCA2) & 0.36 & 0.35 & 0.11 & 0.14 \\
\hline AT5G01630 & Breast cancer 2 susceptibility protein (BRCA2B) & 0.42 & 0.37 & 0.07 & 0.10 \\
\hline AT4G30870 & Crossover junction endonuclease (MUS81) & 0.06 & -0.14 & 0.17 & 0.18 \\
\hline AT5G39770 & Crossover junction endonuclease (MUS81) & 0.03 & 0.07 & -0.15 & -0.10 \\
\hline AT1G04020 & BRCA1-associated RING domain protein 1 (BARD1) & 0.27 & 0.33 & 0.06 & -0.28 \\
\hline AT4G21070 & BRCA1-associated RING domain protein 1 (BRCA1) & 0.10 & -0.14 & -0.11 & 0.00 \\
\hline AT1G77320 & Topoisomerase (DNA) // binding protein 1 (MEI1) & 0.19 & 0.07 & -0.16 & -0.18 \\
\hline AT4G02110 & Topoisomerase (DNA) I/ binding protein 1 & 0.16 & -0.22 & -0.15 & -0.10 \\
\hline AT5G54260 & Double-strand break repair protein (MRE11) & 0.71 & 0.89 & 0.75 & 0.58 \\
\hline AT2G31970 & $D N A$ repair protein (RAD50) & 0.46 & 0.58 & -0.06 & -0.11 \\
\hline АT3G02680 & Nibrin / (NBS1) & -0.15 & 0.02 & -0.12 & -0.37 \\
\hline AT2G28560 & RAD51-like protein 1 (RAD51B) & 0.4 & 0.92 & 0.92 & 0.21 \\
\hline AT2G45280 & RAD51-like protein 2 (RAD51C) & -0.11 & -0.33 & 0.29 & 0.17 \\
\hline AT1G07745 & RAD51-like protein 3 (RAD51D) & 0.10 & 0.08 & 0.78 & 0.33 \\
\hline AT1G05490 & DNA repair and recombination protein (RAD54) & -0.35 & 0.26 & -0.29 & -0.04 \\
\hline АT3G24340 & DNA repair and recombination protein (RAD54) & -0.14 & -0.15 & -0.57 & 0.05 \\
\hline AT3G42670 & DNA repair and recombination protein (RAD54) & 0.25 & 0.14 & -0.72 & -0.22 \\
\hline AT5G20420 & DNA repair and recombination protein (RAD54) & 0.05 & 0.32 & -0.08 & 0.1 \\
\hline AT2G16390 & DNA repair and recombination protein (RAD54) & 0.15 & 0.18 & 0.00 & -0.03 \\
\hline AT3G19210 & DNA repair and recombination protein (RAD54) & -0.20 & -0.46 & -0.04 & 0.15 \\
\hline AT5G64520 & DNA-repair protein (XRCC2) & -0.76 & -0.62 & 0.12 & -0.13 \\
\hline AT5G57450 & DNA-repair protein (XRCC3) & 0.22 & 0.01 & 0.69 & -0.36 \\
\hline AT1G64750 & 26 proteasome complex subunit (DSS1) & -1.13 & -0.40 & 0.40 & -0.22 \\
\hline AT5G45010 & 26 proteasome complex subunit (DSS1) & -0.82 & -0.28 & 0.45 & 0.06 \\
\hline АT2G21800 & Crossover junction endonuclease (EME1) & 0.13 & 0.36 & 0.35 & 0.43 \\
\hline AT2G22140 & Crossover junction endonuclease (EME1) & -0.5 & 0.07 & -0.06 & -0.3 \\
\hline AT1G10930 & Bloom syndrome protein (RECQ4A) & 0.05 & 0.18 & -0.42 & -0.12 \\
\hline AT1G60930 & Bbloom syndrome protein (RECQ4B) & -0.41 & -0.05 & -1.18 & -0.33 \\
\hline АT3G05740 & Bloom syndrome protein (RECQI1) & 0.04 & 0.05 & 0.35 & 0.4 \\
\hline AT4G35740 & Bloom syndrome protein (RecQ/3) & -0.24 & 0.03 & 0.06 & 0.02 \\
\hline AT1G80210 & BRCA1/BRCA2-containing complex subunit 3 (BRCC36A) & -0.14 & -0.27 & -0.10 & -0.17 \\
\hline АT3G06820 & $B R C A 1 / B R C A 2$-containing complex subunit 3 (BRCC36B) & -0.14 & -0.23 & -0.05 & -0.10 \\
\hline AT5G42470 & BRCA1-A complex subunit (BRE) & 0.08 & 0.18 & 0.14 & 0.19 \\
\hline AT1G20720 & Fanconi anemia group J protein & 0.54 & 0.50 & 0.49 & 0.71 \\
\hline AT1G20750 & Fanconi anemia group J protein & 0.41 & 0.82 & 0.67 & 0.74 \\
\hline AT4G32960 & BRISC and BRCA1-A complex member 1 & -0.01 & 0.11 & -0.04 & -0.15 \\
\hline
\end{tabular}

Fig. 7 Comparative transcriptome expression profiles of genes associated with homologous recombination from OsJAC1-overexpressing lines and a wild-type control with and without gamma irradiation 


\begin{tabular}{|c|c|c|c|c|c|}
\hline Gene locus & Gene name (definition) & wt vs. \#16-5 & wt vs. \#18-2 & $\begin{array}{l}\text { wt 100Gy vs. } \\
\# 16-5 \text { 100Gy }\end{array}$ & $\begin{array}{l}\text { wt } 100 G \text { ys. } \\
\# 18-2 \text { 100Gy }\end{array}$ \\
\hline AT5G27620 & Cyclin $H\left(\mathrm{CrCH}_{1} 1\right)$ & -0.16 & -0.16 & 0.19 & -0.05 \\
\hline AT1G55750 & Transcription initiation factor TFIIH subunit 1 & 0.21 & 0.31 & 0.23 & 0.20 \\
\hline АT3G61420 & Transcription initiation factor TFIIH subunit 1 & 0.29 & 0.32 & 0.34 & 0.39 \\
\hline AT1G05055 & Transcription initiation factor TFIIH subunit 2 & 0.13 & 0.05 & 0.16 & -0.01 \\
\hline AT1G18340 & Transeription initiation factor TFIIH subunit 3 & -0.18 & -0.23 & -0.02 & -0.22 \\
\hline AT4G17020 & Transcription initiation factor TFIIH subunit 4 & 0.00 & 0.03 & 0.06 & -0.02 \\
\hline AT4G30820 & $C D K$-activating kinase assembly factor MAT1 & -0.34 & -0.01 & 0.55 & 0.15 \\
\hline AT5G20570 & RING-box protein 1 (RBX1) & -0.55 & -0.08 & 0.25 & 0.11 \\
\hline AT5G16630 & Xeroderma pigmentosum C-complementing protein (RAD4) & 0.15 & 0.07 & 0.26 & 0.25 \\
\hline AT1G16190 & UV excision repair protein RAD23 & -0.18 & -0.03 & 0.05 & -0.09 \\
\hline AT1G79650 & UV excision repair protein $R A D 23$ & -0.13 & 0.09 & 0.10 & -0.02 \\
\hline АT3G02540 & UV excision repair protein RAD23 & 0.22 & 0.26 & 0.24 & 0.31 \\
\hline AT5G38470 & UV excision repair protein RAD23 & -0.01 & 0.11 & -0.27 & -0.25 \\
\hline AT5G46210 & Cullin 4 & 0.41 & 0.45 & -0.04 & -0.17 \\
\hline AT1G12400 & TFIIH basal transcription factor complex TTD-A subunit & -0.53 & 0.18 & 0.03 & -0.16 \\
\hline AT4G05420 & DNA damage-binding protein 1 (DDB 1A) & 0.63 & 0.56 & -0.19 & 0.01 \\
\hline AT4G21100 & DNA damage-binding protein 1 (DDB1B) & 0.76 & 0.68 & -0.02 & 0.20 \\
\hline AT5G58760 & DNA damage-binding protein 2 (DDB2) & 0.19 & 0.05 & -0.1 & -0.29 \\
\hline АT3G05210 & $D N A$ excision repair protein ERCC-1 & -0.16 & 0.05 & 0.13 & -0.05 \\
\hline AT1G03190 & DNA excision repair protein ERCC-2 (UVHG) & -0.16 & 0.31 & -0.08 & -0.43 \\
\hline AT5G41370 & DNA excision repair protein ERCC-3 (XPB1) & 0.35 & 0.40 & -0.04 & -0.04 \\
\hline AT5G41360 & DNA excision repair protein ERCC-3 (XPB2) & 0.33 & 0.39 & -0.11 & -0.16 \\
\hline AT5G41150 & DNA excision repair protein ERCC-4 (UVH1) & 0.47 & 0.37 & -0.05 & 0.01 \\
\hline AT3G28030 & DNA excision repair protein ERCC-5 (UVH3) & 0.43 & 0.40 & -0.06 & -0.11 \\
\hline AT2G18760 & DNA excision repair protein ERCC- 6 & 0.38 & 0.33 & -0.38 & -0.28 \\
\hline AT1G27840 & $D N A$ excision repair protein ERCC-8 & -0.21 & -0.29 & -0.07 & -0.14 \\
\hline AT1G19750 & $D N A$ excision repair protein $E R C C-8$ & -0.37 & -0.36 & -0.10 & -0.24 \\
\hline AT1G66750 & Cyclin-dependent kinase 7 (CAK4) & -0.21 & -0.19 & 0.06 & 0.10 \\
\hline АT1G73690 & Cyclin-dependent kinase $7(C D K D 1 ; 1)$ & -0.61 & -0.2 & 0.37 & 0.04 \\
\hline AT1G18040 & Cyclin-dependent kinase 7 (CDKD1;3) & -0.47 & -0.36 & -0.06 & 0.25 \\
\hline
\end{tabular}

\begin{tabular}{|c|c|c|c|c|c|}
\hline Gene locus & Gene name (definition) & wt vs. \#16-5 & wt vs. \#18-2 & $\begin{array}{l}\text { wt 100Gy vs. } \\
\# 16-5100 G y\end{array}$ & $\begin{array}{l}\text { wt } 100 \mathrm{~Gy} \text { vs. } \\
\# 18-2100 \mathrm{~Gy}\end{array}$ \\
\hline AT1G65070 & DNA mismatch repair protein MutS2 & 0.41 & 0.24 & -0.11 & -0.02 \\
\hline AT4G09140 & DNA mismatch repair protein $M L H 1$ & 0.13 & 0.29 & 0.00 & -0.16 \\
\hline AT3G18524 & DNA mismatch repair protein $M S H 2$ & 0.30 & 0.19 & 0.40 & 0.55 \\
\hline AT4G25540 & $D N A$ mismatch repair protein $M S H 3$ & 0.68 & 0.97 & 0.17 & 0.60 \\
\hline AT4G02070 & DNA mismatch repair protein $M S H G$ & 0.66 & 0.64 & 0.09 & 0.09 \\
\hline АT3G24495 & DNA mismatch repair protein $M S H G$ & 0.60 & 0.41 & 0.18 & 0.47 \\
\hline AT4G35520 & DNA mismatch repair protein $M L H 3$ & 0.79 & 0.61 & 0.62 & 0.43 \\
\hline AT1G18090 & Exonuclease 1 & -0.16 & -0.37 & -0.23 & -0.28 \\
\hline AT1G29630 & Exonuclease 1 & 0.05 & -0.08 & 0.18 & 0.43 \\
\hline
\end{tabular}

\begin{tabular}{|c|c|c|c|c|c|}
\hline Gene locus & Gene name (definition) & wt vs. \#16-5 & wt vs. \#18-2 & $\begin{array}{l}\text { wt } 100 \mathrm{~Gy} \text { vs. } \\
\# 16-5100 \mathrm{~Gy}\end{array}$ & $\begin{array}{l}\text { wt } 100 \mathrm{~Gy} \text { vs. } \\
\# 18-2 \quad 100 \mathrm{~Gy}\end{array}$ \\
\hline AT1G10520 & DNA polymerase lambda & 0.00 & 0.52 & 0.33 & 0.16 \\
\hline AT5G57160 & DNA ligase 4 & 0.55 & 0.45 & 0.03 & 0.10 \\
\hline AT1G16970 & ATP-dependent DNA helicase 2 subunit 1 (KU70) & -0.08 & 0.14 & 0.21 & 0.14 \\
\hline AT1G48050 & ATP-dependent DNA helicase 2 subunit 2 (KU80) & -0.13 & 0.38 & -0.23 & -0.48 \\
\hline AT3G23100 & DNA-repair protein XRCC4 & -0.37 & -0.36 & 0.41 & 0.03 \\
\hline
\end{tabular}

Fig. 8 Comparative transcriptome expression profiles for genes related to (a) nucleotide excision repair, (b) mismatch repair, and (c) nonhomologous recombination repair from OSJAC1-overexpressing lines and a wild-type control before and after gamma irradiation 
genes in response to gamma radiation in OsJAC1overexpressing lines indicates that OsJAC1 may function in the overlapping pathways between DDR and pathogen defense.

DDR serves as a regulation signal for many DNA repair pathways, which have presumably evolved to maintain genome integrity. DDR also regulates apoptosis, senescence, and the DNA replication process [38]. DNA replication is a key step for cell proliferation, because genome duplication for transmission is essential in all organisms. Figure 6 shows the expression levels of genes associated with DNA replication in OsJAC1-overexpressing lines. It is of particular interest that the transcript numbers of MCM4-MCM7 were increased in OsJAC1-overexpressing lines. MCM proteins are licensing factors for DNA replication [39]. For formation of the pre-replicative complex, MCMs form a complex with OCR, CDT1, and CDC6/ CDC18 [40-42]. MCM genes have been identified in A. thaliana, Zea mays, and O. sativa and are expressed in young tissues with replicating cells [39, 43]. We observed significant accumulation of MCM6 transcripts after exposure to gamma radiation in OsJAC1-overexpressing lines (Fig. 6). Dang et al. [44] noted that the MCM6 single subunit was essential in abiotic stress tolerance in plants. Upregulation of MCM6 was detected in pea plants exposed to salinity and cold stresses, and overexpression of pea MCM6 in tobacco conferred resistance to salinity stress. Therefore, upregulation of $M C M$ transcripts by OsJAC1 overexpression indicates that OsJAC1 may participate in the regulation of DNA replication stresses induced by salt and gamma radiation.

RPA, which is a single-strand DNA-binding protein that is composed of three subunits (RPA1, 2, 3) is associated with DNA repair, meiosis, and DNA replication and activates cellular responses to DNA damage [45]. Low levels of $R P A 3 A$ and $R P A 3 B$ transcripts were detected in OsJAC1-overexpressing lines before irradiation compared to a wild-type control, but gamma irradiation increased the numbers of these RPA transcripts (Fig. 6). DNA polymerase epsilon is composed of four subunits: one large subunit TILl (Pol2) and three small subunits, DNAbinding protein (DPB) 2, 3, and 4 [46]. The exact functions of polymerase delta and epsilon remain controversial, but polymerase epsilon is associated with replicative error repair and replicative stress sensing [47, 48]. In OsJAC1-overexpressing lines, TIL1 and TIL2 were upregulated compared to levels in wild-type plants, but genes for both subunits were slightly downregulated following gamma irradiation compared to the levels before irradiation (Fig. 6). Arabidopsis mutant abo4-1, which has a partially defective polymerase epsilon subunit, was resistant to replicative stress but hypersensitive to DNA damaging agents, including zeiocin [48, 49]. Furthermore, overexpression of polymerase epsilon small subunit DPB2 impaired DNA replication in Arabidopsis. Thus, we conclude that OsJAC1 overexpression altered expression of genes involved in DNA replication, implicating OsJAC1 function in DNA replication.

\section{OsJAC1 may coordinate with MRE11 and ATM to enhance DNA repair}

Cellular response to DNA damage is regulated the protein kinases ATM and ATR, which are activated by different types of DNA damage [50-52]. ATM is mainly activated in response to DSBs, while ATR is activated in response to stalled replication forks. Canman et al. [53] observed ATM activation in response to DSB-inducing ionizing radiation in mammalian cells. In the present study, OsJAC1-overexpressing lines exhibited greater ATM transcript expression than the wild-type control in the absence of irradiation (Fig. 7), while no difference in the numbers of ATR transcripts were observed between the transgenic lines and a control (data not shown). We also observed increased MRE11 expression in OsJAC1-overexpressing lines compared to the wild-type control (Fig. 7). MRE11 is a component of the MRN complex, which includes radiation sensitive 50 (RAD50) and Nijmegen breakage syndrome 1 (NBS1) and serves as the sensor of DSBs. This complex is also important in DNA damage repair, DNA replication, meiosis, and genome stability [54]. Following binding to DSBs, the MRN complex activates ATM $[55,56]$, but this complex is not required for ATR activation [57]. Interactions between MRE11 and DNA replication have been noted. Specifically, MRE11 is necessary for the recovery of hydroxyurea-induced replication stress in HeLa cells, and the MRN complex and RPA co-localized and interacted following treatment with either hydroxyurea or UV light [58]. Taken together, these results suggest that OsJAC1 regulates DNA damage perception and DNA repair as well as in DNA replication via coordination with ATM and MRE11.

Furthermore, we examined the role of OsJAC1 in nucleotide excision repair. The UV-damage DNA-binding protein complex was first reported in human cells. Overexpression of $D D B 1 A$ and $D D B 1 B$ enhanced resistance to UV radiation in Arabidopsis, whereas two knock-out mutants, $d d b 1 a$ and $d d b 1 b$, were susceptible [59, 60]. Our results are consistent with this previous report, as $D D B 1 A$ and $D D B 1 B$ transcripts in OsJAC1-overexpressing transgenic lines were increased (Fig. 8a). Mismatched nucleotide bases that result from insertion, deletion and misincorporation lead to polymerase mis-incorporation and incorrect recombination of DNA. DNA mismatch repair (MMR) systems detect and repair these mismatched nucleotides, and Mut genes play important roles in genome maintenance [61]. MSH (MutS homologs) and MHL (MutL homologs) are highly conserved proteins; although, these factors have diverse cellular functions [62]. In the present study, Arabidopsis lines overexpressing OsJAC1 had greater expression of MSH3, MSH6, and MHL3 
transcripts than the wild-type control (Fig. 8b). Previously, MSH2-deficient mouse cells were found to have low survival rates after X-ray irradiation, and $\mathrm{MSH} 2$ required relocalization of RAD51 and MRE11 in the G2 phase of the cell cycle [63]. Together, these results may indicate that OsJAC1 is linked with both MMR and NER in the DDR pathway.

\section{Conclusions}

Figure 9 displays a scheme illustrating the hyperresistance to ionizing radiation conferred by OsJAC1 overexpression. In summary, we suggest that the observed upregulation of $A T M$ and MRE11 by OsJAC1 overexpression provides evidence of enhanced DNA damage perception. We interpret the observed transcriptional changes of genes encoding DNA polymerases, RPAs, and MCMs as evidence for the activation of DNA damage checkpoints in response to replication stress in OsJAC1-overexpressing lines. Thus, activation of both DNA damage perception and DNA damage checkpoints by OsJAC1 overexpression may confer hyper-resistance to gamma radiation in Arabidopsis.

\section{Methods}

\section{Plant growth conditions}

Oryza sativa spp. japonica cv. Ilpoom was obtained from the Rural Development Administration of Korea. Arabidopsis thaliana ecotype Landsberg erecta, originated from the Arabidopsis Biological Resource Center, was acquired from Kumho Life Science Laboratory of Chonnam National University in Korea. Rice plants were grown at $30{ }^{\circ} \mathrm{C}$ with a cycle of $16 \mathrm{~h}$ light followed by $8 \mathrm{~h}$ dark. Arabidopsis plants were cultured at $23^{\circ} \mathrm{C}$ under the light and dark cycle as described above.

\section{Generation of OsJAC1-overexpressing Arabidopsis lines}

OsJAC1 (XM_015763269) cDNA was amplified with gene-specific primers using the polymerase chain reaction (PCR). The PCR conditions were as follows: one cycle at $94{ }^{\circ} \mathrm{C}$ for $5 \mathrm{~min}$; 35 cycles at $92^{\circ} \mathrm{C}$ for $1 \mathrm{~min}$, $57^{\circ} \mathrm{C}$ for $1 \mathrm{~min}$, and $72^{\circ} \mathrm{C}$ for $1 \mathrm{~min}$; and one cycle at $72^{\circ} \mathrm{C}$ for $5 \mathrm{~min}$. Primer sequences for OsJAC1 were $5^{\prime}$ ATG GCT GAT CCC AGC AAG CTG CA-3' and 5'TTA GAT CGG CTG CAC GTA GAC ACC AAC-3'. The amplified OsJAC1 cDNA was sub-cloned into the $\mathrm{pCR}^{\mathrm{Tm}} 8 / \mathrm{GW} / \mathrm{TOPO}^{\circ}$ vector and then transferred into the

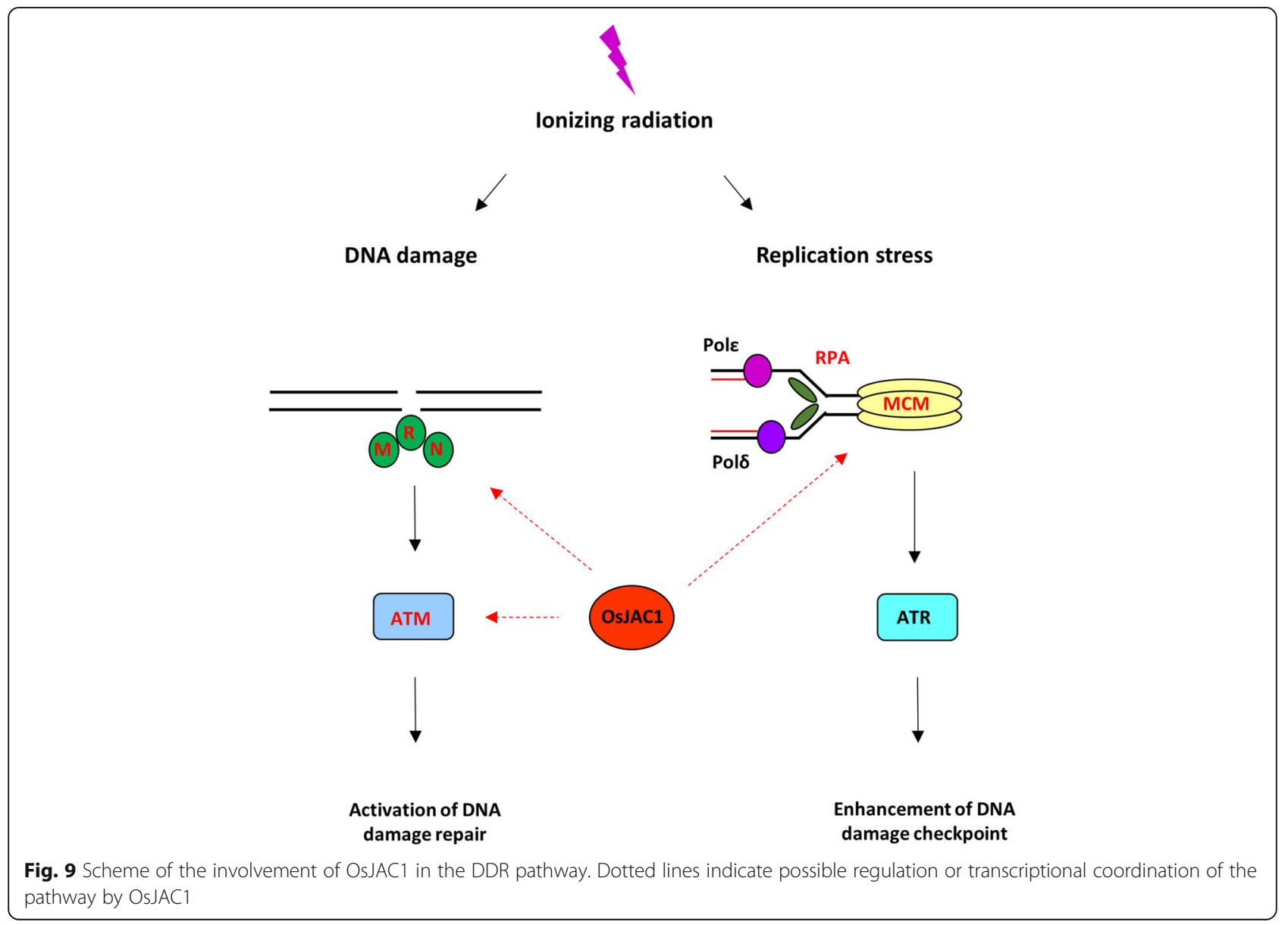


pMDC83 vector using the Gateway cloning system according to the manufacturer's instructions. The OsJAC1-overexpressing construct was introduced into Agrobacterium tumefaciens LBA4404 using electroporation. Arabidopsis plants were transformed using the floral dip method [64]. Seeds were harvested from the dipped Arabidopsis plants. To identify insertion of the OsJAC1-overexpressing construct, selection was performed using MS media containing $50 \mu \mathrm{g} / \mathrm{ml}$ kanamycin. To obtain homozygous OsJAC1-overexpressing lines, segregation analyses of seeds from the selected progenies were carried out. Six homozygous lines with OsJAC1 overexpression were identified.

\section{Conditions of gamma irradiation}

Rice seeds were germinated on Murashige and Skoog (MS; Duechefa, Haarlem, Netherlands) solid media containing $0.8 \%$ agar and $1 \%$ sucrose. Two-week-old seedlings were irradiated with gamma radiation using a gamma irradiator $\left({ }^{60} \mathrm{Co}\right.$, approximately $150 \mathrm{TBq}$; Atomic Energy of Canada, Ltd., Ottawa, Ontario) for $12 \mathrm{~h}$ at the Korea Atomic Energy Research Institute. To identify dose-dependent effects, various doses $(100,200,300$, and $400 \mathrm{~Gy}$ ) of gamma radiation were used for each sample. Seedling samples were obtained at different times $(0-168 \mathrm{~h})$ after gamma irradiation for analysis. For confirmation of time-dependent expression of OsJAC1 in response to ionizing radiation, dry rice seeds were exposed to gamma radiation at different doses $(100,200$, 300 , and $400 \mathrm{~Gy}$ ), and then seeds were germinated on MS media. Two-week-old rice seedlings were harvested.

\section{Imposition of salinity stress and treatment with plant hormones}

For plant hormone treatment, rice seeds were germinated in MS solid media containing 0.8\% agar and 1\% sucrose. Two-week-old rice seedlings were treated with $1 \mathrm{mM}$ SA (Sigma, St. Louis, MO, USA) and $0.1 \mathrm{mM} \mathrm{JA}$ (Sigma). Samples were collected at 6, 12, and $24 \mathrm{~h}$ after each treatment. For imposition of heat stress, 2-weekold rice seedlings were incubated at $45^{\circ} \mathrm{C}$ for $2 \mathrm{~h}$. Samples were obtained $0,3,6$, and $12 \mathrm{~h}$ after heat treatment.

\section{RNA isolation and quantitative reverse transcription (RT)- PCR}

Total RNA was isolated using RNeasy plant mini kit (Qiagen, Hilden, Germany) according to the manufacturer's instructions, and then DNA contamination was removed using RNase-free DNase (Takara, Kyoto, Japan). The cDNA synthesis was performed using the Superscript ${ }^{\circ}$ III reverse transcriptase (Invitrogen, Carlsbad, CA, USA). For quantitative RT-PCR, cDNA amplification was performed using Power SYBR Green PCR master mix (Thermo Fisher Scientific, Rockford, IL, USA) with the CFX ${ }^{\text {TM }}$ Real-Time System
(Bio-Rad, Hercules, CA, USA). Conditions for the PCR reactions were as follows: one cycle at $94{ }^{\circ} \mathrm{C}$ for $5 \mathrm{~min}$; $40 \mathrm{cy}$ cles at $92^{\circ} \mathrm{C}$ for $30 \mathrm{~s}, 60^{\circ} \mathrm{C}$ for $30 \mathrm{~s}$, and $72{ }^{\circ} \mathrm{C}$ for $30 \mathrm{~s}$; one cycle at $72^{\circ} \mathrm{C}$ for $5 \mathrm{~min}$. Primer sequences for OsJAC1 were 5'-CGT CTC GAA AGC ATC ACA TT-3' and 5'-CGG CAT GGT CAA GGT AAG TA-3' and for Actin were $5^{\prime}$ TGA AGT GCG ACG TGG ATA TTA G-3' and 5' -CAG TGA TCT CCT TGC TCA-3'.

\section{Western blot analysis}

For total protein extraction, whole plant tissues were homogenized in extraction buffer $(100 \mathrm{mM}$ Tris-Cl, $\mathrm{pH} 7.5$; $1 \mathrm{mM}$ ethylenediaminstetraacetic acid; $0.5 \mathrm{NP}-40 ; 150$ $\mathrm{mM} \mathrm{NaCl} ; 3 \mathrm{mM}$ dithiothreitol) and protease inhibitor (Sigma). Total proteins were separated on a sodium dodecyl sulfate-polyacrylamide gel (Sigma) by electrophoresis and then transferred onto Immobilon-P membranes (Millipore, Burlington, MA, USA). Immunodetection was performed with a rat anti-GFP antibody (Abcam, Cambridge, MA, USA) and visualized using a chemiluminescence ECL kit (Thermo Fisher Science, Waltham, MA, USA) according to the manufacturer's instruction.

\section{Comparative transcriptome analysis}

Two biological plant sample replicates were prepared for transcriptome analysis. RNA isolation was performed as described above. Transcriptome analysis was conducted as described by Koo et al. [65]. Briefly, mRNA-Seq paired-end libraries were constructed using the Illumina TruSeq RNA Sample Preparation Kit v2 (Illumina, San Diego, CA, USA), and the KAPA library quantification kit (Kapa Biosystems, Wilmington, MA, USA) was utilized for quantification of the library according to the manufacturer's instruction. The cDNA libraries were sequenced using an Illumina HiSeq2000 (Illumina). For short-read mapping, reads were mapped to reference transcripts using the bowtie software (Langmead et al., 2009). DEGs $(p \leq 0.01$ and fold-change $\geq 2)$ commonly expressed between the transgenic lines in comparison with the control were selected from the mapped reads.

\section{Statistical analyses}

One-way analyses (ANOVA) were performed for statistical analyses of quantitative RT-PCR and plant growth measurement using $\mathrm{R}$ program (version 3.6.1).

\section{Supplementary information}

Supplementary information accompanies this paper at https://doi.org/10. 1186/s12870-019-2056-8.

Additional file 1: Figure S1. Root growth of OsJAC1-overexpressing plants in response to salt stress.

Additional file 2: Table S1. Expression levels of anotated transciprts in OsJAC1-overexpressing Arabidopsis lines. 


\section{Abbreviations}

ATM: Ataxia Telangiectasia Mutated protein; DDR: DNA damage response: DEGs: Differentially expressed genes; DSB: Double-strand breaks; OsJAC1: Rice mannose-binding jacalin-related lectin

\section{Acknowledgements}

Not applicable.

\section{Authors' contributions}

IJ generated transgenic lines and analyzed data for transgenic plants. JWA performed transcriptome analysis, wrote the manuscript and arranged all data. IJJ and SJ carried out RT-PCR analysis. JEH and MJH helped to design experiments. HIC helped to analyze transcriptome data. JBK supervised the work and interpreted data. All authors contributed revision of the manuscript. All authors read and approved the manuscript.

\section{Funding}

This work was funded by the research program of Korea Atomic Energy Research Institute, Republic of Korea. This funding body did not play any role in the design of this study and collection, analysis, and interpretation of data and in writing the manuscript.

\section{Availability of data and materials}

All materials in the current article are available from the corresponding author.

\section{Ethics approval and consent to participate}

This study does not contain any research requiring ethical consent or approval.

\section{Consent for publication}

Not applicable.

\section{Competing interests}

The authors declare that they have no competing interests.

\section{Author details}

'Advanced Radiation Technology Institute, Korea Atomic Energy Research Institute, 29 Geumgu-gil, Jeongeup-si, Jeollabuk-do 56212, Republic of Korea. ${ }^{2}$ Division of Ecological Conservation, Bureau of Ecological Research, National Institute of Ecology, Seocheon 33657, Republic of Korea.

Received: 14 March 2019 Accepted: 26 September 2019 Published online: 18 December 2019

\section{References}

1. Peumans WJ, Van Damme EJ. Lectins as plant defense proteins. Plant Physiol. 1995;109:347-52.

2. Van Damme EJ, Barre A, Rouge P, Peumans WJ. Cytoplasmic/nuclear plant lectins: a new story. Trends Plant Sci. 2004;9(10):484-9.

3. Jiang SY, Ma Z, Ramachandran S. Evolutionary history and stress regulation of the lectin superfamily in higher plants. BMC Evol Biol. 2010;10:79.

4. Y-j H, Z-h Z, L-I S, Olsson S, Wang ZH, Lu GD. Evolutionary analysis of plant jacalin-related lectins (JRLs) family and expression of rice JRLs in response to Magnaporthe oryzae. J Integr Agric. 2018;17:1252-66.

5. Lannoo N, Van Damme EJ. Lectin domains at the frontiers of plant defense. Front Plant Sci. 2014:5:397.

6. Chrispeels MJ, Raikhel NV. Lectins, lectin genes, and their role in plant defense. Plant Cell. 1991;3:1-9.

7. Zhang W, Peumans WJ, Barre A, Astoul CH, Rovira P, Rouge P, Proost P, Truffa-Bachi P, Jalali AA, Van Damme EJ. Isolation and characterization of a jacalin-related mannose-binding lectin from salt-stressed rice (Oryza sativa) plants. Planta. 2000;210(6):970-8.

8. Song $M, X u$ W, Xiang Y, Jia H, Zhang L, Ma Z. Association of jacalin-related lectins with wheat responses to stresses revealed by transcriptional profiling. Plant Mol Biol. 2014;84:95-110.

9. Jiang JF, Han Y, Xing $L, X U$ YY, XU ZH, Chong K. Cloning and expression of a novel cDNA encoding a mannose-specific jacalin-related lectin from Oryza sativa. Toxicon. 2006;47(1):133-9.
10. Jiang J-F, Xu Y-Y, Chong K. Overexpression of OsJAC1, a Lectin gene, suppresses the coleoptile and stem elongation in Rice. J Integr Plant Biol. 2007:49:230-7.

11. Weidenbach D, Esch L, Moller C, Hensel G, Kumlehn J, Hofle C, Huckelhoven $R$, Schaffrath U. Polarized defense against fungal pathogens is mediated by the Jacalin-related Lectin domain of modular Poaceae-specific proteins. Mol Plant. 2016:9(4):514-27.

12. Karran P. DNA double strand break repair in mammalian cells. Curr Opin Genet Dev. 2000;10(2):144-50.

13. Haber JE. Partners and pathways repairing a double-strand break. Trends Genet. 2000;16(6):259-64.

14. Cassidy $\mathrm{CL}$, Lemon JA, Boreham DR. Impacts of low-dose gamma-radiation on genotoxic risk in aquatic ecosystems. Dose Response. 2007;5(4):323-32.

15. Zhou BB, Elledge SJ. The DNA damage response: putting checkpoints in perspective. Nature. 2000;408(6811):433-9.

16. Paques F, Haber JE. Multiple pathways of recombination induced by double-strand breaks in Saccharomyces cerevisiae. Microbiol Mol Biol Rev. 1999;63(2):349-404.

17. Lavin MF, Kozlov S. ATM activation and DNA damage response. Cell Cycle. 2007;6(8):931-42.

18. Lopez-Contreras AJ, Fernandez-Capetillo O. The ATR barrier to replicationborn DNA damage. DNA Repair (Amst). 2010;9(12):1249-55.

19. Sacco E, Hasan MM, Alberghina L, Vanoni M. Comparative analysis of the molecular mechanisms controlling the initiation of chromosomal DNA replication in yeast and in mammalian cells. Biotechnol Adv. 2012;30(1):73-98.

20. Mazouzi A, Velimezi G, Loizou Jl. DNA replication stress: causes, resolution and disease. Exp Cell Res. 2014;329(1):85-93.

21. Errico A, Costanzo V. Mechanisms of replication fork protection: a safeguard for genome stability. Crit Rev Biochem Mol Biol. 2012;47(3):222-35.

22. Jin YW, Na YJ, Lee YJ, An S, Lee JE, Jung M, Kim H, Nam SY, Kim CS, Yang KH, Kim SU, Kim WK, Park WY, Yoo KY, Kim CS, Kim JH. Comprehensive analysis of time- and dose-dependent patterns of gene expression in a human mesenchymal stem cell line exposed to low-dose ionizing radiation. Oncol Rep. 2008;19(1):135-44.

23. Koo KM, Jung S, Kim J-B, Kim SH, Kwon SJ, Jeong W-J, Chung GH, Kang SY, Choi YE, Ahn JW. Effect of ionizing radiation on the DNA damage response in Chlamydomonas reinhardtii. Genes Genomics. 2017;39:63-75.

24. Alscher RG, Donahue JL, Cramer CL. Reactive oxygen species and antioxidants: relationships in green cells. Physiol Plant. 1997;100:224-36.

25. Saha $\mathrm{P}$, Mukherjee A, Biswas AK. Modulation of $\mathrm{NaCl}$ induced DNA damage and oxidative stress in mungbean by pretreatment with sublethal dose. Biol Plant. 2015;59(1):139-146.

26. Lopez E, Arce C, Oset-Gasque MJ, Canadas S, Gonzalez MP. Cadmium induces reactive oxygen species generation and lipid peroxidation in cortical neurons in culture. Free Radic Biol Med. 2006;40(6):940-51.

27. Xiang $Y$, Song M, Wei Z, Tong J, Zhang L, Xiao L, Ma Z, Wang Y. A jacalinrelated lectin-like gene in wheat is a component of the plant defence system. J Exp Bot. 2011;62(15):5471-83.

28. Gorlach J, Volrath S, Knauf-Beiter G, Hengy G, Beckhove U, Kogel KH, Oostendorp M, Staub T, Ward E, Kessmann H, Ryals J. Benzothiadiazole, a novel class of inducers of systemic acquired resistance, activates gene expression and disease resistance in wheat. Plant Cell. 1996;8(4):629-43.

29. Patra J, Sahoo MK, Panda BB. Salicylic acid triggers genotoxic adaptation to methyl mercuric chloride and ethyl methane sulfonate, but not to maleic hydrazide in root meristem cells of Allium cepa L. Mutat Res. 2005:581(1-2):173-80.

30. Gichner T, Menke M, Stavreva DA, Schubert I. Maleic hydrazide induces genotoxic effects but no DNA damage detectable by the comet assay in tobacco and field beans. Mutagenesis. 2000;15(5):385-9.

31. Dona M, Macovei A, Fae M, Carbonera D, Balestrazzi A. Plant hormone signaling and modulation of DNA repair under stressful conditions. Plant Cell Rep. 2013;32(7):1043-52.

32. Mur LA, Kenton P, Atzorn R, Miersch O, Wasternack C. The outcomes of concentration-specific interactions between salicylate and jasmonate signaling include synergy, antagonism, and oxidative stress leading to cell death. Plant Physiol. 2006;140(1):249-62.

33. Mhamdi A, Hager J, Chaouch S, Queval G, Han Y, Taconnat L, Saindrenan P, Gouia H, Issakidis-Bourguet E, Renou JP, Noctor G. Arabidopsis GLUTATHIONE REDUCTASE1 plays a crucial role in leaf responses to intracellular hydrogen peroxide and in ensuring appropriate gene expression through both salicylic acid and jasmonic acid signaling pathways. Plant Physiol. 2010;153(3):1144-60. 
34. Han Y, Chaouch S, Mhamdi A, Queval G, Zechmann B, Noctor G. Functional analysis of Arabidopsis mutants points to novel roles for glutathione in coupling $\mathrm{H}(2) \mathrm{O}(2)$ to activation of salicylic acid accumulation and signaling. Antioxid Redox Signal. 2013;18(16):2106-21.

35. Han Y, Mhamdi A, Chaouch S, Noctor G. Regulation of basal and oxidative stress-triggered jasmonic acid-related gene expression by glutathione. Plant Cell Environ. 2013;36(6):1135-46.

36. Hwang IS, Hwang BK. The pepper mannose-binding lectin gene CaMBL1 is required to regulate cell death and defense responses to microbial pathogens. Plant Physiol. 2011;155(1):447-63.

37. Hadwiger LA, Tanaka K. Non-host resistance: DNA damage is associated with SA signaling for induction of PR genes and contributes to the growth suppression of a pea pathogen on pea endocarp tissue. Front Plant Sci. 2017;8:446.

38. Ciccia A, Elledge SJ. The DNA damage response: making it safe to play with knives. Mol Cell. 2010;40(2):179-204.

39. Springer PS, McCombie WR, Sundaresan V, Martienssen RA. Gene trap tagging of PROLIFERA, an essential MCM2-3-5-like gene in Arabidopsis. Science. 1995;268(5212):877-80.

40. Bell SP. The origin recognition complex: from simple origins to complex functions. Genes Dev. 2002;16(6):659-72.

41. Coleman TR, Carpenter PB, Dunphy WG. The Xenopus Cdc6 protein is essential for the initiation of a single round of DNA replication in cell-free extracts. Cell. 1996;87(1):53-63.

42. Nishitani H, Lygerou Z, Nishimoto T, Nurse P. The Cdt1 protein is required to license DNA for replication in fission yeast. Nature. 2000;404(6778):625-8.

43. $\mathrm{Cho} \mathrm{JH}$, Kim HB, Kim HS, Choi SB. Identification and characterization of a rice MCM2 homologue required for DNA replication. BMB Rep. 2008;41(8):581-6.

44. Dang HQ, Tran NQ, Gill SS, Tuteja R, Tuteja N. A single subunit MCM6 from pea promotes salinity stress tolerance without affecting yield. Plant Mol Biol. 2011;76(1-2):19-34.

45. Aklilu BB, Soderquist RS, Culligan KM. Genetic analysis of the replication protein a large subunit family in Arabidopsis reveals unique and overlapping roles in DNA repair, meiosis and DNA replication. Nucleic Acids Res. 2014;42(5):3104-18.

46. Pursell ZF, Kunkel TA. DNA polymerase epsilon: a polymerase of unusual size (and complexity). Prog Nucleic Acid Res Mol Biol. 2008;82:101-45.

47. Johnson RE, Klassen R, Prakash L, Prakash S. A major role of DNA polymerase delta in replication of both the leading and lagging DNA strands. Mol Cell. 2015;59(2):163-75.

48. Pedroza-Garcia JA, Mazubert C, Del Olmo I, Bourge M, Domenichini S, Bounon R, Tariq Z, Delannoy E, Pineiro M, Jarillo JA, Bergounioux C, Benhamed M, Raynaud C. Function of the plant DNA polymerase epsilon in replicative stress sensing, a genetic analysis. Plant Physiol. 2017;173(3):1735-49.

49. Pedroza-Garcia JA, Domenichini S, Mazubert C, Bourge M, White C, Hudik E, Bounon R, Tariq Z, Delannoy E, Del Olmo I, Pineiro M, Jarillo JA, Bergounioux C, Benhamed M, Raynaud C. Role of the polymerase subunit DPB2 in DNA replication, cell cycle regulation and DNA damage response in Arabidopsis. Nucleic Acids Res. 2016:44(15):7251-66.

50. Culligan K, Tissier A, Britt A. ATR regulates a G2-phase cell-cycle checkpoint in Arabidopsis thaliana. Plant Cell. 2004;16(5):1091-104.

51. Culligan KM, Robertson CE, Foreman J, Doerner P, Britt AB. ATR and ATM play both distinct and additive roles in response to ionizing radiation. Plant J. 2006:48(6):947-61.

52. Abraham RT. Cell cycle checkpoint signaling through the ATM and ATR kinases. Genes Dev. 2001;15(17):2177-96.

53. Canman CE, Lim DS, Cimprich KA, Taya Y, Tamai K, Sakaguchi K, Appella E, Kastan MB, Siliciano JD. Activation of the ATM kinase by ionizing radiation and phosphorylation of p53. Science. 1998;281(5383):1677-9.

54. Czornak K, Chughtai S, Chrzanowska KH. Mystery of DNA repair: the role of the MRN complex and ATM kinase in DNA damage repair. J Appl Genet. 2008;49(4):383-96.

55. Harper JW, Elledge SJ. The DNA damage response: ten years after. Mol Cell. 2007;28(5):739-45.

56. Williams RS, Williams JS, Tainer JA. Mre11-Rad50-Nbs1 is a keystone complex connecting DNA repair machinery, double-strand break signaling, and the chromatin template. Biochem Cell Biol. 2007;85(4):509-20.

57. Cimprich KA, Cortez D. ATR: an essential regulator of genome integrity. Nat Rev Mol Cell Biol. 2008;9(8):616-27.

58. Robison JG, Elliott J, Dixon K, Oakley GG. Replication protein a and the Mre11.Rad50.Nbs1 complex co-localize and interact at sites of stalled replication forks. J Biol Chem. 2004;279(33):34802-10.
59. Koga A, Ishibashi T, Kimura S, Uchiyama Y, Sakaguchi K. Characterization of T-DNA insertion mutants and RNAi silenced plants of Arabidopsis thaliana UV-damaged DNA binding protein 2 (AtUV-DDB2). Plant Mol Biol. 2006; 61(1-2):227-40.

60. Molinier J, Lechner E, Dumbliauskas E, Genschik P. Regulation and role of Arabidopsis CUL4-DDB1A-DDB2 in maintaining genome integrity upon UV stress. PLoS Genet. 2008;4(6):e1000093.

61. Miller JH. Mutators in Escherichia coli. Mutat Res. 1998;409(3):99-106.

62. Fishel R. Mismatch repair. J Biol Chem. 2015;290(44):26395-403.

63. Franchitto A, Pichierri P, Piergentili R, Crescenzi M, Bignami M, Palitti F. The mammalian mismatch repair protein $\mathrm{MSH} 2$ is required for correct MRE11 and RAD51 relocalization and for efficient cell cycle arrest induced by ionizing radiation in G2 phase. Oncogene. 2003;22(14):2110-20.

64. Clough SJ, Bent AF. Floral dip: a simplified method for agrobacteriummediated transformation of Arabidopsis thaliana. Plant J. 1998;16(6):735-43.

65. Koo KM, Jung S, Lee BS, Kim JB, Jo YD, Choi HI, Kang SY, Chung GH, Jeong WJ, Ahn JW. The mechanism of starch over-accumulation in

Chlamydomonas reinhardtii high-starch mutants identified by comparative Transcriptome analysis. Front Microbiol. 2017;8:858.

\section{Publisher's Note}

Springer Nature remains neutral with regard to jurisdictional claims in published maps and institutional affiliations.

\section{Ready to submit your research? Choose BMC and benefit from:}

- fast, convenient online submission

- thorough peer review by experienced researchers in your field

- rapid publication on acceptance

- support for research data, including large and complex data types

- gold Open Access which fosters wider collaboration and increased citations

- maximum visibility for your research: over $100 \mathrm{M}$ website views per year

At BMC, research is always in progress.

Learn more biomedcentral.com/submissions 